UDC 541.11

Yu.P. Pavlovskii, S.I. Gerasimchuk, V.V. Sergeev, G.V. Melnyk, V.B. Vostres

\title{
DETERMINATION OF CRYSTALLIZATION ENTHALPIES OF SOME ORGANIC PEROXIDES BY A DIFFERENTIAL ISOTHERMAL CALORIMETER
}

\author{
Lviv Polytechnic National University, Lviv, Ukraine
}

\begin{abstract}
We developed a method for determination of the crystallization enthalpy of organic substances in a heat-conducting calorimeter at a temperature close to $298 \mathrm{~K}$. Crystallization was conducted in the MID-200 calorimeter using an ampoule technique. The volume of ampoules, which contain the supercooled liquids, was approximately $0.2 \mathrm{~cm}^{3}$. The residual pressure was $650 \mathrm{~Pa}$ to lessen the heat loss. A few crystals of the material under investigation were employed as the crystallization centers. Based on the results of the experiment, the crystallization enthalpies of dicumyl peroxide, peroxyoctanoic acid and di-tert-butylperoxy isophthalate were determined. The vaporization and sublimation enthalpies of peroxyoctanoic acid were assessed using an ampoule method in the calorimeter. It was established that dicumyl peroxide which was supercooled $14 \mathrm{~K}$ below the fusion temperature exhibited a $20 \%$ increase in crystallization enthalpy as compared with that calculated from the difference between vaporization and sublimation enthalpy. At the same time, the crystallization enthalpy of peroxyoctanoic acid supercooled by $5 \mathrm{~K}$ was equal to that calculated from the difference between vaporization and sublimation enthalpy within the limiting experimental error. The received data show that the proposed method is promising for determining the heat of crystallization of liquids that are able to exist in a supercooled state during some time.
\end{abstract}

Keywords: isothermal heat-conducting calorimeter; supercooled liquid; crystallization enthalpy; vaporization enthalpy; sublimation enthalpy; dicumyl peroxide; peroxyoctanoic acid; di-tert-butylperoxy isophthalate.

DOI: $10.32434 / 0321-4095-2021-135-2-90-94$

\section{Introduction}

When studying the properties of substances by calorimetric method, only those calorimetry potentialities are used that are mentioned in the manuals and traditionally accepted. The heats of chemical reaction, vaporization, sublimation as well as the heats of dissolution and mixing are mostly determined by means of an isothermal heatconducting calorimeter [1]. Expansion of the application of various types of calorimeters could allow obtaining more characteristics by using available research facilities.

The fusion (crystallization) enthalpy of materials is usually determined either by a scanning calorimeter at the melting point or by indirect methods. Indirect methods imply the calculation of a difference between sublimation and vaporization enthalpy which in turn is determined at different temperatures or by the temperature dependence of saturated vapor pressure, the calorimetry of dissolving substances and the data of differential thermal analysis [2].

In this work, we offer the procedure for determining the crystallization enthalpy of substances using an isothermal heat-conducting calorimeter at $298 \mathrm{~K}$, this technique is applied to establish the crystallization enthalpies of three different organic peroxides: dicumyl peroxide, peroxyoctanoic acid and di-tert-butylperoxy isophthalate.

\section{Experimental}

When determining vaporization and sublimation enthalpies of several organic peroxides in an isothermal heat-conducting microcalorimeter [3], we detected that some of them are liable to a long-term existence as supercooled liquids at room temperature. These properties of substances were used for determining crystallization enthalpies according to the method, which had been previously used for the determination of the vaporization enthalpies [4]. The

(C) Yu.P. Pavlovskii, S.I. Gerasimchuk, V.V. Sergeev, G.V. Melnyk, V.B. Vostres, 2021

Yu.P. Pavlovskii, S.I. Gerasimchuk, V.V. Sergeev, G.V. Melnyk, V.B. Vostres 
investigated substances in a liquid state were placed in thin-walled glass spherical ampoules $\left(\sim 0.2 \mathrm{~cm}^{3}\right)$ with a tapered tip and sealed. Afterwards, the ampoule was carried into a glass cell of the calorimeter; the trace crystals of the material under investigation were put onto the bottom of the cell as crystallization centers. The calorimeter temperature was kept slightly below the melting temperature, but sufficient for the investigated material to be in a supercooled liquid state for some time. To avoid heat loss to air from the open-ended cell, the absolute pressure was set to about $650 \mathrm{~Pa}$, which is higher than the saturation vapor pressure of the investigated compounds at experimental temperature [5].

Starting from the breaking of the ampoule in the calorimeter, the calorimetric signal was recorded, which was caused by the heat release during material's crystallization. After finishing the experiment, the specific crystallization enthalpy $\left(\mathrm{J} \mathrm{g}^{-1}\right)$ was calculated according to the following equation:

$$
\Delta_{\text {cryst }} \mathrm{H}=\mathrm{K} \cdot \Sigma / \mathrm{m} \text {, }
$$

where $K=7.130 \pm 0.016$ is the constant of the calorimetric cell $\left(\mathrm{W} \mathrm{V}^{-1}\right)$; $\mathrm{m}$ is the crystallizing material weight $(\mathrm{g}) ; \Sigma$ represents the digital integrator reading $(\mathrm{V} s)$.

The constant of the calorimetric cell was the same as when measuring vaporization enthalpies at $298 \mathrm{~K}$ and it was determined in much the same way by vaporizing substances with the reliable vaporization values $\left(\Delta_{\text {vap }} \mathrm{H}_{298}\right)$ of decane, dodecane and tetradecane that are accepted to be $51.42 \pm 0.21,61.52 \pm 0.62$ and $71.73 \pm 0.72 \mathrm{~kJ} \mathrm{~mol}^{-1}$, respectively [6]. In our opinion, this was completely enough since the crystallization experiments were carried out practically in identical conditions and in a slightly rarefied medium. To eliminate the systematic error in some isolated experiments, we determined the calorific effect of ampoule breaking, which was less than $0.01 \mathrm{~J}$ and less than the calorimeter sensitivity within the investigated experimental range of crystallization enthalpy.

The crystallization enthalpies of dicumyl peroxide $\left(\mathrm{C}_{6} \mathrm{H}_{5}-\mathrm{C}\left(\mathrm{CH}_{3}\right)_{2}-\mathrm{OO}-\mathrm{C}\left(\mathrm{CH}_{3}\right)_{2}-\mathrm{C}_{6} \mathrm{H}_{5}\right)$, di-tert-butylperoxy isophthalate $\left(\left(\mathrm{CH}_{3}\right)_{3} \mathrm{C}-\mathrm{OO}-\right.$ $\left.\mathrm{CO}-\mathrm{C}_{6} \mathrm{H}_{4}-\mathrm{CO}-\mathrm{OO}-\mathrm{C}\left(\mathrm{CH}_{3}\right)_{3}\right)$ and peroxyoctanoic acid $\left(\mathrm{CH}_{3}(\mathrm{CH})_{6} \mathrm{CO}-\mathrm{OOH}\right)$ were determined according to the proposed method. Among these substances, di-tert-butyl peroxy terephthalate also had the property of being in a supercooled state for a long time. However, its crystallization, even in the presence of the crystals, lasted several days, which did not allow measuring its crystallization enthalpy.
Technical dicumyl peroxide was purified via threefold crystallization from methanol and subsequent chromatography through aluminium oxide.

Peroxyoctanoic acid was synthesized by the reaction of octanoic acid, hydrogen peroxide and sulfuric acid which were taken in a 1:1:1 molar ratio, respectively. $60 \%$ solution of $\mathrm{H}_{2} \mathrm{O}_{2}$ was dropwise added to the solution of octanoic acid in $96 \% \mathrm{H}_{2} \mathrm{SO}_{4}$ initially cooled to $273 \mathrm{~K}$, the temperature being kept no more than $290 \mathrm{~K}$. After completion of the reaction, the mixture was poured out onto crushed ice and the peroxyacid sediment was filtered off. The peroxyoctanoic acid was purified by double crystallization from hexane and subsequent sublimation in vacuo at $13.3 \mathrm{~Pa}$ and $301 \mathrm{~K}$.

Di-tert-butylperoxy isophthalate was synthesized by the reaction of sodium salt of tertbutyl hydroperoxide with isophthaloyl dichloride at 273-278 K. The product was purified via threefold crystallization from a diethyl ether-hexane mixture (1:1 (vol.)).

The synthesized peroxides were identified by elemental analysis, iodometric determination of active oxygen and IR spectrometry. A fusion curve method [7] was used to estimate the purity of the investigated substances.

Tables $1-3$ shows the primary experimental data regarding the crystallization enthalpies of the investigated substances except peroxyoctanoic acid, the vaporization and sublimation enthalpies of which were found by an ampoule method [4].

Table 1

Primary data regarding experimental determination of the crystallization enthalpies of the peroxides under investigation

\begin{tabular}{c|c|c|c}
\hline $\mathrm{T}, \mathrm{K}$ & $\mathrm{m} \cdot 10^{3}, \mathrm{~g}$ & $\Sigma, \mathrm{V} \mathrm{s}$ & $-\Delta_{\text {cryst }} \mathrm{H}, \mathrm{J} \mathrm{g}^{-1}$ \\
\hline \multicolumn{4}{|c}{ Dicumyl peroxide, $\mathrm{s}-1$} \\
\hline 298.2 & 123.69 & 1.5097 & 87.03 \\
\hline 297.9 & 129.21 & 1.5783 & 87.09 \\
\hline 297.9 & 140.21 & 1.7077 & 86.84 \\
\hline 298.0 & 172.21 & 2.1010 & 86.99 \\
\hline \multicolumn{4}{c}{ di-tert-Butylperoxy isophthalate, $1-\mathrm{g}$} \\
\hline 298.3 & 141.55 & 1.4053 & 70.79 \\
\hline 298.3 & 155.03 & 1.5428 & 70.96 \\
\hline 298.0 & 134.20 & 1.3727 & 72.93 \\
\hline 298.0 & 117.40 & 1.2008 & 72.93 \\
\hline 298.4 & 178.53 & 1.7992 & 71.86 \\
\hline \multicolumn{4}{|c|}{ Octaneperoxoic acid, $1-\mathrm{g}$} \\
\hline 300.2 & 74.67 & 2.0235 & 193.2 \\
\hline 300.2 & 73.69 & 1.9788 & 191.5 \\
\hline 299.9 & 81.38 & 2.1707 & 190.2 \\
\hline 299.8 & 101.06 & 2.7682 & 195.3 \\
\hline 299.9 & 113.79 & 3.1550 & 197.7 \\
\hline \multicolumn{4}{c}{} \\
\hline
\end{tabular}


Table 2 vaporization and sublimation enthalpies taken from

Primary data regarding the experimental determination of the sublimation enthalpy of octaneperoxoic acid

\begin{tabular}{c|c|c|c}
\hline $\mathrm{T}, \mathrm{K}$ & $\mathrm{m} \cdot 10^{3}, \mathrm{~g}$ & $\Sigma, \mathrm{V} \mathrm{s}$ & $\Delta_{\text {sub }} \mathrm{H}, \mathrm{J} \mathrm{g}^{-1}$ \\
\hline 298.2 & 34.42 & 2.8623 & 592.9 \\
\hline 298.3 & 39.94 & 3.2794 & 585.4 \\
\hline 298.4 & 56.06 & 4.6179 & 587.3 \\
\hline 298.4 & 42.97 & 3.5118 & 582.7 \\
\hline 298.3 & 35.91 & 2.9293 & 581.6 \\
\hline 298.3 & 39.29 & 3.2406 & 588.1 \\
\hline \multicolumn{4}{|c}{} \\
\hline
\end{tabular}

Table 3

Primary data regarding the experimental determination of the vaporization enthalpy of octaneperoxoic acid

\begin{tabular}{c|c|c|c}
\hline $\mathrm{T}, \mathrm{K}$ & $\mathrm{m} \cdot 10^{3}, \mathrm{~g}$ & $\Sigma, \mathrm{V} \cdot \mathrm{s}$ & $\Delta_{\text {vap }} \mathrm{H}, \mathrm{J} / \mathrm{g}^{-1}$ \\
\hline 308.1 & 45.17 & 2.4933 & 393.6 \\
\hline 308.2 & 45.48 & 2.4821 & 389.1 \\
\hline 308.1 & 61.30 & 3.3291 & 387.2 \\
\hline 308.3 & 67.74 & 3.5240 & 370,9 \\
\hline 308.4 & 61.17 & 3.3132 & 386.2 \\
\hline 308.2 & 45.72 & 2.4855 & 387.6 \\
\hline \multicolumn{4}{|l}{} \\
\hline
\end{tabular}

[3] is closer to the value given elsewhere [8], where the fusion enthalpy was determined in an adiabatic calorimeter at fusion temperature $\left(\Delta_{\text {fus }} \mathrm{H}_{312.4}=\right.$ $=28.14 \mathrm{~kJ} \mathrm{~mol}^{-1}$ ). The observed $20 \%$ difference cannot be explained by the fact that the crystallization temperature of supercooled dicumyl peroxide is $14 \mathrm{~K}$ lower than the fusion temperature, since the calculation $[2,6]$ gave only a $5 \%$ decrease in the fusion enthalpy. It is quite possible that this difference is caused by the formation of primary structures within the supercooled liquid and correspondingly gives a significant reduction in the crystallization caloric effect.

Standard deviations of the average values of thermodynamic characteristics given in Table 4 were calculated using Student's test for the confidence level of 0.05 .

We realize that the developed method cannot be widely used; it is applicable only to the substances that are disposed to be in a supercooled state for a long period of time. However, in our opinion, this is not a very rare case for rather pure substances.

Table 4

Phase transition enthalpies for investigated substances

\begin{tabular}{|c|c|c|c|c|}
\hline Substance & $\mathrm{T}_{\text {fus }}, \mathrm{K}$ & $\begin{array}{c}\text { Substance } \\
\text { purity, mol.\% }\end{array}$ & Phase transition $(\mathrm{T}, \mathrm{K})$ & $\Delta_{\text {trans }} \mathrm{H}, \mathrm{kJ} \mathrm{mol}^{-1}$ \\
\hline \multirow{4}{*}{ Dicumyl peroxide } & \multirow{4}{*}{$312.0 \pm 0.2$} & \multirow{4}{*}{99.93} & supercooled liquid-solid (298.0) & $-23.52 \pm 0.17$ \\
\hline & & & solid-gas (308.4) [3] & $108.0 \pm 2.9[3]$ \\
\hline & & & liquid-gas (313.0) [3] & $80.78 \pm 0.78[3]$ \\
\hline & & & liquid-solid & $-27.42 \pm 3.0^{*}$ \\
\hline Di-tert-butylperoxy isophthalate & $328.8 \pm 0.2$ & 99.91 & supercooled liquid-solid (298.2) & $-22.31 \pm 0.51$ \\
\hline \multirow{4}{*}{ Octaneperoxoic acid } & \multirow{4}{*}{$305.0 \pm 0.2$} & \multirow{4}{*}{99.60} & supercooled liquid-solid (300.0) & $-31.01 \pm 0.75$ \\
\hline & & & solid-gas (298.3) & $96.4 \pm 1.2$ \\
\hline & & & liquid-gas (308.2) & $64.4 \pm 1.6$ \\
\hline & & & liquid-solid & $-32.0 \pm 2.0^{*}$ \\
\hline
\end{tabular}

*Note: Calculated by the subtraction of the vaporization and sublimation enthalpies.

\section{Results and conclusions}

Based on the experimental calorimetric measurements, the molar enthalpies for the phase transition of the investigated compounds were calculated (Table 4). It can be seen that the crystallization enthalpy of peroxyoctanoic acid, which was calculated as the sublimation enthalpy subtracted from the vaporization one, is equal to that determined by the calorimetric method within an error limit. Meanwhile, the crystallization enthalpy of dicumyl peroxide which is calculated by subtraction the

\section{REFERENCES}

1. Sergeev V.V. Enthalpy of mixing of methacrylic acid with organic solvents at 293 K // Russ. J. Phys. Chem. A. 2016. - Vol.90. - P.575-578.

2. Thermodynamic characteristics of the melting and dissolution of crystalline furan-2-carboxylic and 3-(furyl)-2propenoic acids in organic solvent / Sobechko I.B., Van-ChinSyan Yu.Ya., Gorak Yu.I., Kochubei V.V., Prokop R.T., Velichkivska N.I., et al. // Russ. J. Phys. Chem. A. - 2015. Vol.89. - P.919-925. 
3. Thermochemical properties of tert-butyl and cumyl derivatives of peroxide compounds / Pavlovskii Yu.P., Kachurina N.S., Gerasimchuk S.I., Van-Chin-Syan Yu.Ya. // Russ. J. Phys. Chem. A. - 2013. - Vol.87. - P.1253-1258.

4. Лебедев Ю.А., Мирошниченко Е.А. Термохимия парообразования органических веществ. - М.: Наука, 1981. - 216 с.

5. Термодинамічні властивості кисневмісних органічних сполук. Довідник / Ван-Чин-Сян Ю.Я., Собечко І.Б., Дібрівний В.М., Сергеєв В.В. та ін. - Львів: Національний ун-т «Львівська політехніка», 2012. - $141 \mathrm{c}$.

6. Chickos J.S., Acree W.E. Enthalpies of vaporization of organic and organometallic compounds, 1880-2002 // J. Phys. Chem. Ref. Data. - 2003. - Vol. 32. - Article No. 519.

7. Александров Ю.И. Точная криометрия органических веществ. - М.: Химия, 1975. - 160 с.

8. Acree W., Chickos J.S. Phase transition enthalpy measurements of organic and organometallic compounds and ionic liquids. Sublimation, vaporization, and fusion enthalpies from 1880 to 2015. Part 2. $\mathrm{C}_{11}-\mathrm{C}_{192} / /$ J. Phys. Chem. Ref. Data. 2017. - Vol.46. - Article No. 013104.

Received 10.06.2020

\section{ВИЗНАЧЕННЯ ЕНТАЛЬПІЙ КРИСТАЛІЗАЦІЇ ДЕЯКИХ ОРГАНІЧНИХ ПЕРОКСИДІВ В ДИФЕРЕНЦЙНОМУ ІЗОТЕРМІЧНОМУ КАЛОРИМЕТРІ}

Ю.П. Павловський, С.І. Герасимчук, В.В. Сергеєв, Г.В. Мельник, В.Б. Вострес

Запропоновано методику визначення ентальпії кристалізації органічних речовин в ізотермічному теплопровідному калориметрі за температури, що близька до 298 К. Процес кристалізації здійснювали на калориметрі МІД-200 із застосуванням ампульної методики. Об'єм ампул, що містили переохолоджені рідини, складав близько $0,2 \mathrm{~cm}^{3}$, залишковий тиск для зменшення тепловтрат 650 Па. Для ініціювання процесу кристалізації використовували деяку невелику кількість кристалів речовини, що досліджувалась, як центри кристалізації. Наведено результати визначення ентальпій кристалізації дикумилпероксиду, пероксиоктанової кислоти і ди-трет-бутилпероксиізофталату. Також калориметрично за ампульною методикою визначені ентальпії випаровування і сублімації пероксиоктанової кислоти. Встановлено, що ентальпія кристалізації переохолодженого на 14 K нижче температури плавлення дикумилпероксиду на $20 \%$ більша, за розраховану за різницею ентальпій випаровування і сублімації. У той же час, ентальпія кристалізації переохолодженої на 5 К пероксиоктанової кислоти, в межах похибки експерименту, збігається з розрахованою за різницею ентальпій випаровування і сублімації. Одержані експериментальні дані демонструють можливість використання даної методики для визначення теплоти кристалізації рідин, які здатні певний час знаходитися в переохолодженому стані.

Ключові слова: ізотермічний теплопровідний калориметр, переохолоджена рідина, ентальпія кристалізації, ентальпія випаровування, ентальпія сублімації, дикумилпероксид, пероксиоктанова кислота, ди-третбутилпероксиізофталат.

\section{DETERMINATION OF CRYSTALLIZATION ENTHALPIES OF SOME ORGANIC PEROXIDES BY A DIFFERENTIAL ISOTHERMAL CALORIMETER}

Yu.P. Pavlovskii *, S.I. Gerasimchuk, V.V. Sergeev, G.V. Melnyk, V.B. Vostres

Lviv Polytechnic National University, Lviv, Ukraine

* e-mail: yurii.p.pavlovskyi@Ipnu.ua

We developed a method for determination of the crystallization enthalpy of organic substances in a heat-conducting calorimeter at a temperature close to $298 \mathrm{~K}$. Crystallization was conducted in the MID-200 calorimeter using an ampoule technique. The volume of ampoules, which contain the supercooled liquids, was approximately $0.2 \mathrm{~cm}^{3}$. The residual pressure was $650 \mathrm{~Pa}$ to lessen the heat loss. A few crystals of the material under investigation were employed as the crystallization centers. Based on the results of the experiment, the crystallization enthalpies of dicumyl peroxide, peroxyoctanoic acid and di-tertbutylperoxy isophthalate were determined. The vaporization and sublimation enthalpies of peroxyoctanoic acid were assessed using an ampoule method in the calorimeter. It was established that dicumyl peroxide which was supercooled $14 \mathrm{~K}$ below the fusion temperature exhibited a $20 \%$ increase in crystallization enthalpy as compared with that calculated from the difference between vaporization and sublimation enthalpy. At the same time, the crystallization enthalpy of peroxyoctanoic acid supercooled by $5 \mathrm{~K}$ was equal to that calculated from the difference between vaporization and sublimation enthalpy within the limiting experimental error. The received data show that the proposed method is promising for determining the heat of crystallization of liquids that are able to exist in a supercooled state during some time.

Keywords: isothermal heat-conducting calorimeter; supercooled liquid; crystallization enthalpy; vaporization enthalpy; sublimation enthalpy; dicumyl peroxide; peroxyoctanoic acid; di-tert-butylperoxy isophthalate.

\section{REFERENCES}

1. Sergeev VV. Enthalpy of mixing of methacrylic acid with organic solvents at 293 K. Russ J Phys Chem A. 2016; 90 : 575-578. doi: 10.1134/S0036024416030274.

2. Sobechko IB, Van-Chin-Syan YuYa, Gorak YuI, Kochubei VV, Prokop RT, Velichkivska NI, et al. Thermodynamic characteristics of the melting and dissolution of crystalline furan2-carboxylic and 3-(furyl)-2-propenoic acids in organic solvent. Russ J Phys Chem A. 2015; 89: 919-925.

doi: 10.1134/S003602441506028X.

3. Pavlovskii YuP, Kachurina NS, Gerasimchuk SI, VanChin-Syan YuYa. Thermochemical properties of tert-butyl and cumyl derivatives of peroxide compounds. Russ J Phys Chem A. 2013; 87: 1253-1258. doi: 10.1134/S003602441307025X.

4. Lebedev YA, Miroshnichenko EA. Termokhimiya paroobrazovaniya organicheskikh veshchestv: spravochnik [Thermochemistry of vaporization of organic substances: a handbook]. Moscow: Nauka; 1981. 216 p. (in Russian).

5. Van-Chin-Syan YY, Sobechko IB, Dibrivnyi VM, Serheiev VV. Termodynamichni vlastyvosti kysnevmisnykh organichnykh rechovyn. Dovidnyk [Thermodynamic properties of oxygen-containing organic compounds: a handbook]. Lviv: Lviv Polytechnic National University; 2012. 141 p. (in Ukrainian). 
6. Chickos JS, Acree WE. Enthalpies of vaporization of organic and organometallic compounds, 1880-2002. J Phys Chem Ref Data. 2003; 32: 519. doi: 10.1063/1.1529214.

7. Aleksandrov YI. Tochnaya kriometriya organicheskich veshchestv [Precision cryometry of organic substances]. Leningrad: Khimiya; 1975. 160 p. (in Russian).

8. Acree W, Chickos JS. Phase transition enthalpy measurements of organic and organometallic compounds and ionic liquids. Sublimation, vaporization, and fusion enthalpies from 1880 to 2015. Part 2. $\mathrm{C}_{11}-\mathrm{C}_{192 .}$. J Phys Chem Ref Data. 2017; 46: 013104. doi: 10.1063/1.4970519. 